\title{
Ocimum basilicum leaf essential oil and (-)-linalool reduce orofacial nociception in rodents: a behavioral and electrophysiological approach
}

\author{
Antônio M. Venâncio, ${ }^{1}$ Murilo Marchioro, ${ }^{1}$ Charles S. Estavam, ${ }^{1}$ \\ Mônica S. Melo, ${ }^{1}$ Marília T. Santana, ${ }^{1}$ Alexandre S.C. Onofre, ${ }^{1}$ \\ Adriana G. Guimarães, ${ }^{1}$ Makson G. B. Oliveira, ${ }^{1}$ Péricles B Alves, ${ }^{2}$ \\ Hugo de Carvalho Pimentel, ${ }^{1}$ Lucindo J. Quintans-Júnior ${ }^{*}$,
}

${ }^{1}$ Departamento de Fisiologia, Universidade Federal de Sergipe, Brazil,

${ }^{2}$ Departamento de Química, Universidade Federal de Sergipe, Brazil.
Revista Brasileira de Farmacognosia Brazilian Journal of Pharmacognosy 21(6): 1043-1051, Nov./Dec. 2011

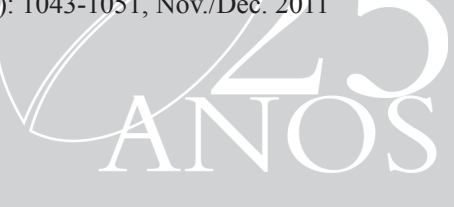

Article

Received 20 Sep 2010

Accepted 20 Nov 2010

Available online 26 Aug 2011

Keywords:

CNS excitability

essential oil

linalool

Ocimum basilicum

orofacial nociception

ISSN 0102-695X

http://dx.doi.org/10.1590/S0102$695 \mathrm{X} 2011005000147$

\section{Introduction}

The orofacial region is one of the most densely innervated (by the trigeminal nerve) areas of the body, which focuses some of the most common acute pains, i.e. those accompanying the pathological states of the teeth and the related structures. It is also the site of frequent chronic (post-herpetic neuralgia, migraine) and referred pains (Raboisson \& Dallel, 2004). Furthermore, many of the difficulties in the management of acute and chronic orofacial pain conditions stem from a lack of recognition and understanding of orofacial pain mechanisms (Miranda et al., 2009).

Pain is a complex integrative phenomenon resulted from the integration of three components: sensory-discriminative, affective-emotional and cognitive-evaluative (Liu \& Chen, 2009). When pain becomes chronic, the sensory dysfunction is accompanied by several brain disorders, such as anxiety, amnesia and depression (Ling et al., 2007; Narita et al., 2006). Cumulative behavioral, electrophysiological and molecular data suggested important roles for the hippocampal formation (HF) in pain process (Cecarelli et al., 1999; Liu \& Chen, 2009). The main afferent input to the HF is the entorhinal cortex (EC), via the so called perforant path, which terminates on the dendrites of the dentate gyrus (DG). From there, the sensory information enters the trisynaptic hippocampal pathway to be processed. It is believed that this process is involved in the motivational dimension of pain (Melzak, 2008).

The management of pain continues being a major challenge for medicine. Opioids, anticonvulsants and non-steroidal anti-inflammatory drugs (NSAIDs) are the main agents used to relieve acute and chronic pain (Pace et al., 2006). However, numerous therapeutic approaches are being used to better control the widespread clinical problem that affect a significant proportion of the human population (Lu et al., 2009). An actual approach is to develop new biological compound 
that inhibits orofacial pain from natural products, such as medicinal plants or its secondary metabolites, with enhanced efficacy and minimal side-effects (HolandaPinto et al., 2008; Quintans-Júnior et al., 2010; Siqueira et al., 2010).

Essential oils are natural products generally obtained from medicinal plants that exhibit a variety of biological properties, such as analgesic (Almeida et al., 2001), anticonvulsant (De Sousa et al., 2007; QuintansJúnior et al., 2008a), anxiolytic and hypnotic (Almeida et al., 2009). Monoterpenes are the main components of these essential oils and the pharmacological properties of many medicinal plants have been attributed to them (Peana et al., 2004; De Sousa et al., 2006; De Sousa et al., 2007; Melo et al., 2010).

Several Ocimum species (Lamiaceae) are used to treat central nervous system (CNS) disorders in various parts of the world and its anticonvulsant activity is frequently reported (Quintans-Júnior et al., 2008b; Oliveira et al., 2009). Ocimum basilicum L. essential oil is rich in monoterpenes, such as $\delta$-cadinol $(10.2 \%)$, estragole $(22.6 \%)$, and linalool (47.3\%) (Mazutti et al., 2006). However, the major chemical constituent of $O$. basilicum essential oil, named "Maria Bonita" [a new variety of Ocimum derived from the accession PI 197442, from the Germplasm Bank North Central Regional PI Station (USA)] is linalool (76.93 \%) (Blank et al., 2007). (-)-Linalool is one natural enantiomer monoterpene compound of many essential oils, which is known to exhibit several biological activities such as CNS depressant, antinociceptive, anxiolytic and anticonvulsant (Peana et al., 2002; Peana et al., 2006; Kamatou \& Viljoen, 2008; Batista et al., 2008). Until now, no data exists about the possible orofacial antinociception effect of (-)-linalool and $O$. basilicum leaf essential oil (LEO).

The aim of this work was to evaluate the effect of LEO and LIN in formalin-, glutamate- and capsaicin-induced orofacial nociception on mice and to investigate if these substances could also interfere with the hippocampal neuronal excitability.

\section{Material and Methods}

\section{Animals}

The experiments were conducted using male Swiss mice (25-32 g) and male Wistar rats (50-80 g), housed at $22 \pm 2{ }^{\circ} \mathrm{C}$ under a 12-h light/12-h dark cycle (lights on at 06:00) and with access to food and water ad libitum. The animals were acclimatized to the laboratory for at least $1 \mathrm{~h}$ before testing and were used only once throughout the experiments. The experiments were performed after gaining approval of the protocol by the Animal Care and Use Committee (CEPA/UFS
$\mathrm{N}^{\mathrm{o}}$ 07/08) at the Federal University of Sergipe and followed the current guidelines for the care of laboratory animals and the ethical guidelines for investigations of experimental pain in conscious animals (Zimmermann, 1983). The numbers of animals (eight per group) and intensities of noxious stimuli used were the minimum necessary to demonstrate the consistent effects of the drug treatments. All nociception tests were carried out by the same visual observer.

\section{Drug and reagents}

For all in vivo experiments the following agents were used: (-)-linalool (97\% purity, Sigma, USA), morphine hydrochloride (União Química, Brazil), 37\% formaldehyde (Vetec, Brazil), Tween 80 (polyoxyethylenesorbitan monolate), glutamate and capsaicin (Sigma, USA). Vehicle was Tween $80 \quad 0.2 \%$ dissolved in $0.9 \%$ saline solution and used to dilute the test drugs. In those protocols the agents were injected intraperitoneally (i.p.) at a dose volume of $0.1 \mathrm{~mL} / 10 \mathrm{~g}$, with exception of algogen agents, such as formalin, glutamate and capsaicin, which were injected subcutaneously (s.c.) into the right upper lip. For the electrophysiological experiments the following agents were used: (-)-linalool, lidocaine hydrochloride (Hipolabor, Brazil) $(0.5 \mathrm{mg} / \mathrm{mL})$ and 6,7-dinitroquinoxaline-2,3-dione (DNQX; $2.5 \mu \mathrm{g} / \mathrm{mL}$ ) (Sigma,USA). The LEO and LIN were dissolved with dimethy sulphoxide (DMSO) (Vetec, Brazil) and absolute ethyl alcohol (Vetec, Brazil) at a ratio $1: 10(\mathrm{v} / \mathrm{v})$, and, then, diluted at $100 \mathrm{~mL}$ in artificial cerebrospinal fluid (ACSF). The DMSO and absolute ethyl alcohol at the concentrations used had no effect on the cell membrane current (Ohkubo \& Kitamura, 1997; Ardjmand et al., 2006). Lidocaine was directly dissolved in ACSF.

\section{Plant material and essential oil extraction}

Leaves were collected from the cultivation of the Ocimum basilicum L. (Lamiaceae) (named "Maria Bonita") obtained at the Research Station "Campus Rural da UFS" of the Federal University of Sergipe, Brazil. $O$. basilicum named "Maria Bonita" was derived from the accession PI 197442 of the Germplasm Bank "North Central Regional PI Station", USA. It is a basil cultivar with a rounded canopy, rose petals and purple sepals. It is cultivated at Brazilian northeast region (Blank et al., 2007). The leaves of $\mathrm{O}$. basilicum were dried in an oven with air renewal and circulation (model MA-037/18) at $40{ }^{\circ} \mathrm{C}$ until complete dehydration has been achieved. The essential oil was obtained by hydrodistillation in a Clevenger-type apparatus using $100 \mathrm{~g}$ of dried leaves. The O. basilicum leaf essential oil (LEO) obtained was dried over anhydrous sodium sulphate, producing yields of $4.75 \mathrm{~mL}(\mathrm{v} / \mathrm{w})$. Gas chromatography-mass spectrometry (GC-MS) and gas chromatography-flame ionization detector (GC-FID) 
analysis were realized to recognize the compounds of the LEO.

\section{Orofacial nociception tests}

Formalin test

Orofacial nociception was induced in mice by s.c. injection of $20 \mu \mathrm{L}$ of $2 \%$ formalin into the right upper lip (perinasal area), using a 27-gauge needle (Clavelou et al., 1995; Luccarini et al., 2006). This volume and percentage concentration of formalin was selected from our pilot study that revealed a nociception-related biphasic behavioural response (face-rubbing) of great intensity at periods of 0-5 min (first phase) and 15-40 min (second phase). Nociception was quantified at those periods by measuring the time (s) that the animals spent face-rubbing in the injected area with its fore- or hindpaws (Luccarini et al., 2006). To assess the effects of test drugs, groups of mice ( $\mathrm{n}=8$, each group) were pretreated systemically with vehicle (tween $800.2 \%$ in distilled water), LEO or $\operatorname{LIN}(50,100$, and $200 \mathrm{mg} / \mathrm{kg}$, i.p. $), 0.5 \mathrm{~h}$ before the local injection of formalin. Morphine (MOR, $5 \mathrm{mg} / \mathrm{kg}$, i.p.), administered $0.5 \mathrm{~h}$ before the algogen, was included as positive control.

\section{Glutamate-induced nociception}

In an attempt to provide more direct evidence concerning the interaction of the LEO or LIN with the glutamatergic system, we separately investigated whether or not the LEO or LIN was able to antagonize glutamate-induced orofacial nociception in mice. The procedure used was similar to that previously described by Beirith et al. (2002) with some alterations, including the local of application according to Quintans-Júnior et al. (2010). A volume of $20 \mu \mathrm{L}$ of glutamate (25 $\mu \mathrm{M} /$ paw prepared in phosphate buffered saline) was injected in the right upper lip (perinasal area), using a 27 -gauge needle. Animals were observed individually for $15 \mathrm{~min}$ following glutamate injection. Nociception quantification was performed at this period measuring the time (s) that the animals spent face-rubbing the injected area with fore- or hindpaws. Mice $(n=8$, per group) were treated with the LEO or LIN $(50,100$, and $200 \mathrm{mg} / \mathrm{kg}$, i.p.), morphine (MOR, $5 \mathrm{mg} / \mathrm{kg}$, i.p.) and vehicle $0.5 \mathrm{~h}$ before glutamate injection.

\section{Capsaicin test}

The orofacial nociception was induced by capsaicin in rodents as described earlier (Pellisier et al., 2002). Mice ( $\mathrm{n}=8$, each group) were injected with capsaicin $(20 \mu \mathrm{L}, 2.5 \mu \mathrm{g})$ subcutaneously into the right upper lip (perinasal area), using a 27- gauge needle.
Capsaicin was dissolved in ethanol, dimethyl sulfoxide and distilled water $(1: 1: 8)$. In a pilot study, rodents manifested nociception-related face-rubbing behaviour following the injection of capsaicin with a high intensity at 10-20 min period. Therefore, nociception quantification was performed at this period measuring the time (s) that the animals spent face-rubbing the injected area with fore- or hindpaws. LEO or LIN $(50,100$, and $200 \mathrm{mg} / \mathrm{kg}$, i.p. $)$ or vehicle were given to animals as described for formalin test, $0.5 \mathrm{~h}$ before the local injection of capsaicin. MOR (5 mg/kg, i.p.), administered $0.5 \mathrm{~h}$ before the algogen, was included as a positive control. An additional group received a similar volume of capsaicin vehicle.

\section{Electrophysiology}

\section{Hippocampal slice preparation}

Animals were anesthetized with ether, their brains were quickly removed and transferred to ACSF as ice cold, which was composed of $(\mathrm{mM}): \mathrm{NaCl} 96.5$; $\mathrm{KC} 1$ 2.6; $\mathrm{CaCl}_{2} 2 ; \mathrm{Mg} \mathrm{SO}_{4} 2 ; \mathrm{NaHCO}_{3} 31.5$; glucose 10 , constantly bubbled with $\mathrm{O}_{2}(95 \%)$ and $\mathrm{CO}_{2}(5 \%)$. The brains were glued on the base of a vibroslicer (WPI, USA) and cut horizontally until finding the hippocampi, which were sliced transversally at 400 $\mu \mathrm{m}$ due to their anatomical position. After one hour of resting, the slices were transferred to the recording chamber (Warner, USA).

\section{Field potential recordings}

The field potentials were recorded on the cellular layer of the hippocampal dentate gyrus, using microelectrodes made from borosilicate glass (od: 1.5 $\mathrm{mm}, \mathrm{AM}$-System, USA), which has resistances from 1-5 $\mathrm{M} \Omega$ when filled with ACSF. Stimulation $(0.1 \mathrm{~ms}, 0.1-$ $0.3 \mathrm{~mA}, 0.05 \mathrm{~Hz}$ ) was applied in the hylus (antidromic) and in the perforant path (ortodromic) with tungsten bipolar electrodes connected to an isolated unit, the Isostim A320 (WPI, USA). Field potentials were amplified by 100X (Axopatch1-D, Molecular Devices, USA), filtered at $2 \mathrm{KHz}$, digitalized at $10 \mathrm{KHz}$, at the Digidata 3220 machine (Molecular Devices, USA) and recorded by the WCP software (Dempster, Univ. of Strathclyde, Scotland).

\section{Pharmacological studies}

As lidocaine $(0.5 \mathrm{mg} / \mathrm{mL})$ is a dependent of voltage sodium channel blocker, we evaluated this effect using LEO $(0.01,0.1,0.5,1 \mathrm{mg} / \mathrm{mL})$ and LIN $(0.5 \mathrm{mg} / \mathrm{mL})$ in comparison with it. These responses were recorded (at $0.05 \mathrm{~Hz}$ ) for ten min or until its 
stabilization. Then, the test substance was perfused for ten minutes before the field potentials were recorded. Unless full recovery of the control response was achieved, only one substance and one dose were tested for each slice. For the dose-response curve of the LEO, 3-4 slices were use for each tested dose.

\section{Statistical analysis}

For the in vivo tests, the data obtained were expressed as the mean \pm SEM and the differences were evaluated by one-way analysis of variance (ANOVA) followed by Tukey's test. The percent of inhibition by an antinociceptive agent was determined using the following formula (Reanmongkol et al., 1994):

\section{Inhibition $\%=100 .($ control-experiment $) /$ control}

For the electrophysiological data, the analysis was performed off line with the WCP software. The amplitude $(\mathrm{mV})$ of the field potentials were measured between the most negative to the most positive peak. For each experiment, the mean amplitude of ten responses before and ten minutes after the perfusion of the tested substances were used. Data were expressed as the mean \pm SEM. For the LEO dose-response curve, data were fitted by a non-linear regression sigmoidal curve, using the Graph Pad Prism (v 4.00) software.

\section{Results}

GC-MS and GC-FID analysis of the essential oil resulted in the identification of 13 compounds, constituting $99.96 \%$ of the total oil. Furthermore, 1,8-cineole, linalool, geraniol and neryl acetate were the main components, comprising $96.89 \%$ of the oil. Linalool was the major component $(76.93 \%)$ of leaves oil (Table 1).

Intraperitoneal administration of LEO or LIN produced a reduction in face rubbing behavior in formalin test (Table 2). All tested doses of LIN produced significantly antinociceptive effect in the first and second phase compared to control group (vehicle). LEO demonstrates, only in high dose, significantly antinociceptive effect in both phases. Morphine was able to reduce nociceptive behaviour in both phases.

The results of the orofacial nociception induced by glutamate and capsaicin tests are represented in Table 3. Pretreatment with LIN or LEO reduced the neurogenic inflammatory nociception induced by capsaicin injection into the right upper lip (perinasal area). This effect was evidenced by suppression of the face rubbing behaviour compared with control group (vehicle). High doses produced a similar effect to morphine $(5 \mathrm{mg} / \mathrm{kg})$. Nociceptive behavior was no find in the control group. At the glutamate test, the administration of LEO or LIN (100 and $200 \mathrm{mg} / \mathrm{kg}$, i.p.) decreased significantly the face rubbing behaviour compared with control group (vehicle).

Table 1. Volatile composition of essential oil of Ocimum basilicum.

\begin{tabular}{cccccc}
\hline Peak & $\begin{array}{c}\text { RT } \\
(\mathrm{min})\end{array}$ & Compounds & $\begin{array}{c}\text { GC/MS } \\
(\%)\end{array}$ & $\begin{array}{c}\text { GC-FID } \\
(\%)\end{array}$ & RI $^{\text {a }}$ \\
\hline 1 & 6.967 & $\alpha$-tujeno & 0.08 & - & 932 \\
2 & 8.225 & sabineno & 0.17 & - & 971 \\
3 & 8.392 & $\beta$-pineno & 0.45 & 0.61 & 976 \\
4 & 10.292 & 1,8 -cineol & 6.66 & 6.25 & 1031 \\
5 & 12.817 & linalol & 76.13 & 76.93 & 1096 \\
6 & 16.333 & $\alpha$-terpineol & 0.49 & 0.65 & 1188 \\
7 and 8 & 18.342 & geraniol* & 11.16 & 11.13 & 1252 \\
9 & 19.567 & acetato de isobornila & 0.15 & - & 1284 \\
10 & 22.842 & acetato de geranila & 3.03 & 2.58 & 1437 \\
11 & 24.675 & $\alpha$-trans-bergamoteno & 0.96 & 0.88 & 1432 \\
12 & 27.308 & $\gamma$-cadineno & 0.17 & 0.33 & 1512 \\
13 & 31.300 & epi- $\alpha$-cadinol & 0.55 & 0.60 & 1642 \\
\hline
\end{tabular}

RT: Time retention; ${ }^{\text {RI: Retention indices (Adams, 2007); *Coelution; }}$ the process whereby two or more chemical compounds elute from a chromatographic column at the same time, making separation and identification difficult.

The stimulation of the hylar region of the dentate gyrus (antidromic stimulation) generated a field potential response in the granular layer, which is characterized by a major negative component (population spike) followed by a small positive phase (Figure 1). Since this response is a consequence of activation of voltage-dependent sodium channels in the axons of the granular cells (Andersen et al., 1971), antagonists of these channels were expected to block the response. As expected, lidocaine $(0.5 \mathrm{mg} / \mathrm{mL})$ reversibly inhibited (about 92\%) the population spike generated by stimulation of the hylus (Figure 1A). Similar effects were seen for LEO $(0.5 \mathrm{mg} / \mathrm{mL})(82.7 \pm 2.6 \%$; Figure $1 \mathrm{~B})$ and LIN $(0.5 \mathrm{mg} / \mathrm{mL})(63.3 \pm 0.8 \%$; Figure $1 \mathrm{C})$. The effect of LEO could not be completely reversed in our experiments.

The IC50 of LEO for this response was $0.1 \pm 0.05$ $\mathrm{mg} / \mathrm{mL}$ as determined by the fitting with a sigmoidal equation of the dose-response curve (Figure 2).

A similar field potential could be generated in the cellular layer by stimulation of the perforant path of the hippocampal slice (ortodromic stimulation). However, in this case the response is a consequence of glutamate release and glutamate receptor activation in the molecular layer. As shown in Figure 3A, DNQX $(2.5 \mu \mathrm{mg} / \mathrm{mL})$, a non-NMDA glutamate receptor antagonist inhibited the response. Similar results were seen for LEO $(0.5 \mathrm{mg} / \mathrm{mL})$ (Figure 3B) and linalool $(0.5 \mathrm{mg} / \mathrm{mL})$ (Figure $3 \mathrm{C})$. In both cases the inhibitory effect was reversible. 
Ocimum basilicum leaf essential oil and (-)-linalool reduce orofacial nociception in rodents - a behavioral and electrophysiological approach

Table 2. Effect of LEO, LIN or morphine on formalin-induced the orofacial pain in mice.

\begin{tabular}{|c|c|c|c|c|c|}
\hline \multirow{3}{*}{ Treatment } & \multirow{3}{*}{ Dose (mg/kg) } & \multicolumn{4}{|c|}{ Face rubbing (s) } \\
\hline & & \multicolumn{2}{|c|}{$0-5 \mathrm{~min}$} & \multicolumn{2}{|c|}{$15-40 \mathrm{~min}$} \\
\hline & & Score of pain ${ }^{\mathrm{a}}$ & $\%$ inhibition & Score of pain ${ }^{a}$ & $\%$ inhibition \\
\hline Vehicle & - & $80.1 \pm 4.4$ & - & $87.7 \pm 15.4$ & - \\
\hline LEO & 50 & $78.6 \pm 9.6$ & 1.9 & $86.0 \pm 5.2$ & 1.9 \\
\hline LEO & 100 & $57.4 \pm 5.79^{\mathrm{b}}$ & 28.3 & $33.1 \pm 13.5^{\mathrm{d}}$ & 62.2 \\
\hline LEO & 200 & $26.6 \pm 4.9^{\mathrm{d}}$ & 66.8 & $1.7 \pm 1.4^{\mathrm{d}}$ & 98.1 \\
\hline LIN & 50 & $16.7 \pm 3.5^{\mathrm{d}}$ & 73.9 & $37.7 \pm 6.8^{\mathrm{c}}$ & 57.0 \\
\hline LIN & 100 & $11.3 \pm 3.0^{\mathrm{d}}$ & 85.9 & $18.6 \pm 5.1^{\mathrm{d}}$ & 78.8 \\
\hline LIN & 200 & $0.7 \pm 0.4^{\mathrm{d}}$ & 99.1 & $1.7 \pm 0.4^{\mathrm{d}}$ & 98.1 \\
\hline Morphine & 5 & $1.7 \pm 0.5^{\mathrm{d}}$ & 97.9 & $0.6 \pm 0.2^{\mathrm{d}}$ & 99.3 \\
\hline
\end{tabular}

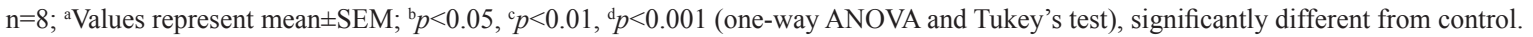

Table 3. Effect of LEO, LIN or morphine on glutamate- and capsaicin- induced the orofacial pain in mice.

\begin{tabular}{|c|c|c|c|c|c|}
\hline \multirow{3}{*}{ Treatment } & \multirow{3}{*}{ Dose $(\mathrm{mg} / \mathrm{kg})$} & \multicolumn{2}{|c|}{ Glutamate } & \multicolumn{2}{|c|}{ Capsaicin } \\
\hline & & \multicolumn{2}{|c|}{ Face rubbing (s) } & \multicolumn{2}{|c|}{ Face rubbing (s) } \\
\hline & & Score of pain ${ }^{\mathrm{a}}$ & $\%$ inhibition & Score of pain ${ }^{\mathrm{a}}$ & $\%$ inhibition \\
\hline Vehicle & - & $53.1 \pm 6.5$ & - & $116.3 \pm 10.3$ & - \\
\hline LEO & 50 & $40.1 \pm 5.6$ & 24.5 & $73.0 \pm 9.6^{\mathrm{b}}$ & 37.2 \\
\hline LEO & 100 & $17.6 \pm 3.3^{\mathrm{c}}$ & 66.9 & $27.1 \pm 8.3^{\mathrm{d}}$ & 76.7 \\
\hline LEO & 200 & $2.3 \pm 1.1^{\mathrm{d}}$ & 95.7 & $8.3 \pm 6.7^{\mathrm{d}}$ & 92.8 \\
\hline LIN & 50 & $34.6 \pm 10.8$ & 34.8 & $69.4 \pm 8.6^{c}$ & 40.3 \\
\hline LIN & 100 & $25.0 \pm 5.1^{\mathrm{b}}$ & 52.9 & $45.1 \pm 12.4^{\mathrm{d}}$ & 61.2 \\
\hline LIN & 200 & $17.4 \pm 5.1^{\mathrm{c}}$ & 67.2 & $7.1 \pm 3.5^{\mathrm{d}}$ & 93.9 \\
\hline Morphine & 5 & $1.6 \pm 0.6^{\mathrm{d}}$ & 97.0 & $1.4 \pm 0.5^{\mathrm{d}}$ & 98.8 \\
\hline
\end{tabular}

$\mathrm{n}=8$; aValues represent mean \pm SEM $;{ }^{\mathrm{b}} p<0.05,{ }^{\mathrm{c}} p<0.01,{ }^{\mathrm{d}} p<0.001$ (one-way ANOVA and Tukey's test), significantly different from control.

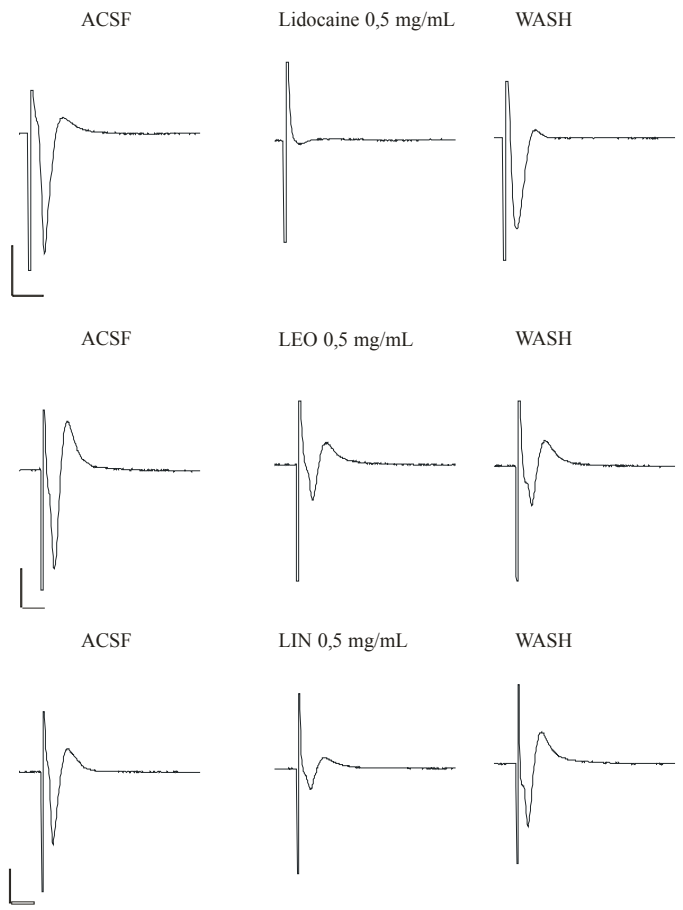

Figure 1. The LEO and linalool block the population spike on dentate gyrus. Representative samples of field potential recordings on the cellular layer of the hippocampal dentate gyrus in response to stimulation of the hylus (antidromic stimulation). Lidocaine (0.5 $\mathrm{mg} / \mathrm{mL})(\mathrm{A})$, the LEO $(0.5 \mathrm{mg} / \mathrm{mL})(B)$ and linalool $(0.5 \mathrm{mg} / \mathrm{mL})(\mathrm{C})$ blocked the population spike of the field responses. The effect was reversed for lidocaine and linalool but not for the LEO. Scale bars: $5 \mathrm{mV}$ and $10 \mathrm{~ms}$ for $\mathrm{A}$ and $\mathrm{C}$ and $3 \mathrm{mV}$ and $10 \mathrm{~ms}$ for B. 


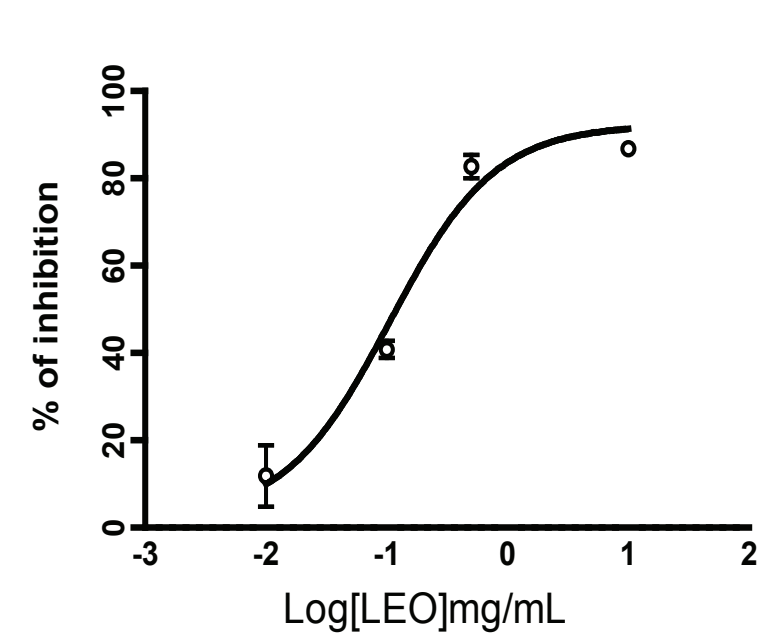

Figure 2. The LEO blocks the population spike on dentate gyrus. Dose-response curve for the LEO on the negative phase (population spike) of the field potential response evoked by the hylus stimulation (antidromic stimulation). Each point on the graph represents the mean \pm SEM of four slices. The curve is a non-linear regression with estimated IC50 of $0.1 \mathrm{mg} / \mathrm{mL}$.

\section{Discussion}

Considerable efforts have recently been made to discover new analgesic agents with increased efficacy and improved side effect profiles. A high number of secondary metabolites obtained from medicinal plants, such as monoterpenes, have been extensively studied, with relevant results (Calixto et al., 2000; Almeida et al., 2001; Melo et al., 2010; Quintans-Júnior et al., 2010). In the present study, LEO and LIN demonstrated to play an antinociceptive effect using orofacial nociception tests and to inhibit hippocampal excitability.

There are relatively few behavioral models in laboratory animals dedicated to study orofacial pain. Indeed, Raboisson \& Dallel (2004) demonstrated that orofacial formalin test in rodents is a well-established pre-clinical model to investigate the efficacy of analgesic compounds in pain of the facial district. The test is based on a chemical stimulus (formalin) and induces a tissue damage that mimics acute post-injury pain in humans.

The orofacial formalin test is a very useful method for to evaluate antinociceptive drugs, and to elucidate its action mechanism (Luccarini et al., 2006). During the test, two phases can at least partially distinct mechanisms of nociception. The first phase is associated to direct stimulation of C-nociceptors, whereas the second phase reflects integration between peripheral (nociceptors) and central (spinal/ brainstem) signaling (Dallel et al., 1995; Capuano et al., 2009). Furthermore, it has been reported that the development of hyperalgesia due to injection of formalin involves glutamatergic system, such as $N$-methylD-aspartate (NMDA) receptors (Beirith et al., 2002;
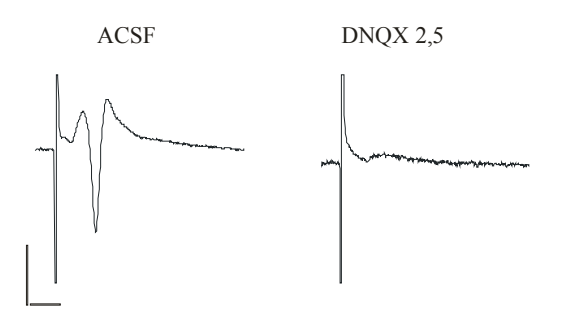

WASH
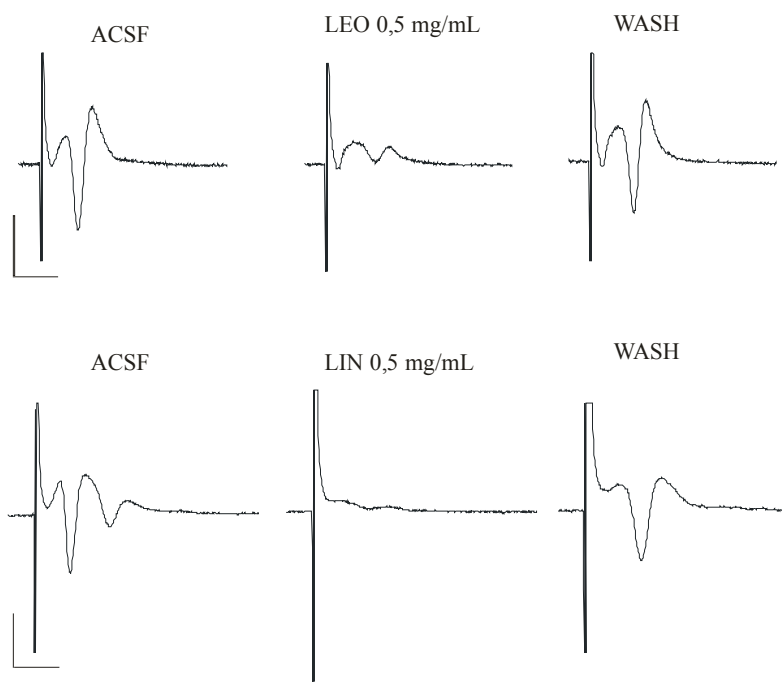

WASH

Figure 3. The LEO and linalool block the synaptic-evoked field response on dentate gyrus. Representative samples of field recordings on the cellular layer of the hippocampal dentate gyrus in response to perforant path stimulation (ortodromic stimulation). DNQX $(2.5 \mu \mathrm{g} / \mathrm{mL})(\mathrm{A})$, the LEO $(0.5 \mathrm{mg} / \mathrm{mL})$ and linalool $(0.5 \mathrm{mg} / \mathrm{mL})$ blocked the field responses. The effect was reversed for the LEO and linalool. Scale bars: $3 \mathrm{mV}$ and $10 \mathrm{~ms}$ for $\mathrm{A}$ and $\mathrm{C}$ and $2 \mathrm{mV}$ and $10 \mathrm{~ms}$ for $\mathrm{B}$.

Luccarini et al., 2006). Pretreatment with LEO or LIN were able to block both phases of the formalin response. The effect was more prominent to LIN.

LIN revealed antinociceptive activity in acetic acid-induced visceral pain in mice; effect that involves activation of both opioidergic and cholinergic neurotransmission (Peana et al., 2003). It is well established that glutamate is involved in transmission of nociceptive signals from peripheral nervous system to the dorsal horn of the spinal cord. It has been reported that the glutamate injection elicited marked nociceptive responses, which is mediated by neuropeptides (such as substance $\mathrm{P}$ ) released from sensory fibers and due to activation of glutamate receptors (i.e. NMDA). NMDA can stimulate the production of a variety of intracellular second messengers, such as nitric oxide (NO) (Carlton et al., 1998). Beirith et al. (2002) described that the nociceptive response induced by glutamate appears to involve peripheral, spinal and supraspinal sites of action and it is greatly mediated by both NMDA and non-NMDA receptors. In this regard, Batista et al. (2008) demonstrated that antinociceptive effect of LIN 
may have relationship with glutamate receptors, namely $\alpha$-amino-3-hydroxy-5-methyl-4-isoxasolepropionic acid (AMPA), NMDA and kainate. Our results confirmed this hypothesis, since pretreatment with LIN significantly protected, at doses 100 and $200 \mathrm{mg} / \mathrm{kg}$ (i.p.), against orofacial formalin test. A similar result was obtained by acute administration of LEO.

AMPA receptors mediate most fast synapses, and are responsible for responses to glutamate in the synapses. Its activation opens the channels for sodium ions, resulting in neuronal membrane for polarization (Sanacora et al., 2008; Zarate \& Manji, 2008). AMPA receptors play an integral role in brain function. Its dysregulation has been implacated in many neurological diseases. There are evidences that AMPA receptors disfunction may be one of the first manifestations of the synaptic dysfunction that underlies Alzheimer's disease (Shepherd \& Huganir, 2007). Glutamatergic AMPA receptors are considered targets to suppress epileptic crisis as they have the property to modulate transmission induced by glutamate (Porto et al., 2007). The kainate receptors are associated with channels voltage-dependent actions and mediate excitatory direct and indirect modulation (Sanacora et al., 2008). NMDA receptors are normally blocked under resting conditions by the obstructing effects of $\mathrm{Mg}^{2+}$ ions. Since the membrane is depolarized, these receptors can be activated by the combined action of two molecules of glutamate and two molecules of glycine or D-serine. Thus, NMDA receptor activation serves as a functional marker of converging excitatory input and produces excitation over longer periods of time. Synaptic NMDA receptors activate mitogen-activated protein kinase (MAPK) and the transcription factor cyclic AMP-Ca ${ }^{2+}$ response elementbinding protein (CREB); induce expression of the gene that encodes brain-derived neurotrophic factor (BDNF); and promote neuronal survival (Sanacora et al., 2008).

NMDA receptors, located in extrasynaptic space, act in an opposite manner, propagating signals that promote cell death (Sanacora et al., 2008). Glutamatergic system changes have been reported in plasma, serum, cerebrospinal fluid and brain tissue of affected individuals with mood disorders (Sanacora et al., 2008). Several classes of antidepressants alter the release glutamatergic substances in several brain regions. Stoll et al. (2007) described antidepressant activity involving the glutamatergic system.

LEO or LIN inhibits the neurogenic inflammatory pain induced by capsaicin injection into the right upper lip (perinasal area). Capsaicin applied to skin, muscle, and other tissues has been shown to produce inflammation, to activate and to sensitize trigeminal and spinal smalldiameter nociceptive afferents as well as dorsal horn neurons. It also evokes nociceptive behavior in animals and intense pain, hyperalgesia and referred pain in humans (Hu et al., 2005; Lam et al., 2009).
The inhibitory effect observed with LEO or LIN on capsaicin-, and in the second phase of formalin-induced face rubbing behaviour may be a result of its possible inhibition on substance P release or due to a direct blocking action on its receptor neurokinin-1 (NK-1) (Holanda-Pinto et al., 2008). In this context, previous studies provided evidence for tonic activation of NK-1 receptors, through NK-1 receptor antagonist SR14033 administration, which blocked the second phase of the orofacial formalin test in rat (Henry et al., 1999; Luccarini et al., 2003). Waning et al. (2007) demonstrated that capsaicin-sensitive transient receptor potential vaniloid 1 (TRPV1) is one of the $\mathrm{Ca}^{+2}$ influx channels involved in cell migration, which plays an important role in pain transduction. Moreover, Honda et al. (2008) suggest that TRPV1 receptor mechanisms in rat facial skin influence nociceptive responses to noxious cutaneous thermal and mechanical stimuli by inducing neuroplastic changes in subnucleus caudalis (Vc) and C1C2 neurons. Genetic approaches in worms, flies and mice have demonstrated the involvement of transient receptor potential (TRP) in a variety of sensory processes that includes thermosensation, mechanosensation, and pain perception (Vogt-Eisele et al., 2007). Besides, microscopic studies have revealed the expression of immunoreactivity for TRPV1 in the trigeminal ganglion (Ichikawa \& Sugimoto, 2001; Hou et al., 2002).

The behavioral experiments suggest that the most of the analgesic effects of LEO could be attributed to LIN, its major component, as revealed by the GC-MS and GC-FID analysis. We gathered further support for this hypothesis in our electrophysiological results, performed in the hippocampal slice preparation (Figures 1, 2 and 3). LEO and LIN inhibited the field potentials activated by the antidromic stimulation of the hylus. These results suggest that these substances interfere with the activation of the voltage-dependent sodium channels present in the granular neurons of the hippocampal dentate gyrus (Andersen et al., 1971). Other electrophysiological data have demonstrated the involvement of the hippocampal formation in pain processing. Khanna \& Sinclair (1992) showed that noxious heat stimulation cause depression of hippocampal neurons in the area CA1. A similar effect was demonstrated with the formalin-induced pain model by electrophysiological methods (Khana \& Zeng, 1999). Besides blocking action potential generation, LEO and LIN could interfere with pain process in the hippocampus as has been demonstrated by Khanna \& Zheng (1999), using electrophysiological methods and by Ceccarelli et al. (1999) using the c-Fos immunohistochemistry.

The DNQX $2.5 \mu \mathrm{g} / \mathrm{mL}$, a non-NMDA glutamate receptor antagonist, inhibited the ortodromic response. Similar results were seen for LEO $(0.5 \mathrm{mg} / \mathrm{mL})$ and LIN $(0.5 \mathrm{mg} / \mathrm{mL})$. These results suggest that LEO and LIN can be considered a non- NMDA glutamate antagonist (AMPA or Kainate blokers). 
In conclusion, our results suggest that LEO and LIN modulate neurogenic and inflammatory pain in the tests of orofacial nociception induced by formalin, capsaicin and glutamate. Antinociceptive activity may be associated with decreased peripheral and central nerve excitability. Our results also support that Ocimum basilicum and (-)-linalool has a therapeutic potential for painful facial, dental disorders and a non-NMDA glutamate receptor antagonist.

\section{Acknowledgements}

We would like to thank the Research Supporting Foundation of State of Sergipe (Fundação de Amparo à Pesquisa do Estado de Sergipe/FAPITEC-SE) for the financial support. Author Antônio M. Venâncio has scholarships from Rede Nordeste de Biotecnologia (RENORBIO).

\section{References}

Adams RP 2007. Identification of essential oil components by gas chromatography/mass spectroscopy. 4 ed. Illinois: Allured Publishing Corporation, Carol Stream.

Almeida RN, Araújo DAM, Goncalves JCR, Montenegro FC, Sousa DP, Leite JR, Mattei R, Benedito MAC, Carvalho JGB, Cruz JS, Maia JGS 2009. Rosewood oil induces sedation and inhibits compound action potential in rodents. J Ethnopharmacol 124: 440-443.

Almeida RN, Navarro DS, Barbosa-Filho JM 2001. Plants with central analgesic activity. Phytomedicine 8: 310-322.

Andersen P, Bliss TV, Skrede KK 1971. Unit analysis of hippocampal polulation spikes. Exp Brain Res 13: 208221.

Ardjmand A, Fathollahi Y, Sayyah M, Kamalinejad M, Omrani A 2006. Eugenol depresses synaptic transmission but does not prevent the induction of long-term potentiation in the CA1 region of rat hippocampal slices. Phytomedicine 13: 146-151.

Batista PA, Werner MFP, Oliveira EC, Burgos L, Pereira P, Silva Brum LF, Santos ARS 2008. Evidence for the involvement of ionotropic glutamatergic receptors on the antinociceptive effect of $(-)$-linalool in mice. Neurosc Lett 440: 299-303.

Beirith A, Santos ARS, Calixto JB 2002. Mechanisms underlying the nociception and paw oedema caused by injection of glutamate into the mouse paw. Brain Res 924: 219-228.

Blank AF, Souza EM, Arrigoni-Blank MF, Paula JWA, Alves PB 2007. "Maria Bonita", uma cultivar de manjericão tipo linalol. Pesq Agropec Bras 42: 1811-1813.

Calixto JB, Beirith A, Ferreira J, Santos AR, Cechinel Filho V, Yunes RA 2000. Naturally occurring antinociceptive substances from plants. Phytother Res 14: 401-418.

Capuano A, Corato A, Treglia M, Tringali G, Russo CD, Navarra $\mathrm{P}$ 2009. Antinociceptive activity of buprenorphine and lumiracoxib in the rat orofacial formalin test: a combination analysis study. Eur J Pharmacol 605: 5762.

Carlton SM, Zhou S, Coggeshall RE 1998. Evidence for the interaction of glutamate and NK1 receptors in the periphery. Brain Res 2: 229-238.

Ceccarelli I, Scaramuzzino A, Aloisi AM 1999. Effects of formalin pain in hippocampal c-fos expression in male and female rats. Pharmacol Biochem Behav 64: 797-802.

Clavelou P, Dallel R, Orliaguel T, Woda A, Raboisson P 1995. The orofacial formalin test in rats: effect of different formalin concentrations. Pain 62: 295-301.

Dallel R, Raboisson P, Clavelou P, Saade M, Woda A 1995. Evidence for a peripheral origin of the tonic nociceptive response to subcutaneous formalin. Pain 61: 11-16.

De Sousa DP, Gonçalves JC, Quintans-Júnior LJ, Cruz JS, Araujo DAM, Almeida RN 2006. Study of anticonvulsant effect of citronellol, a monoterpene alcohol, in rodents. Neurosci Lett 401: 231-235.

De Sousa DP, Quintans-Júnior LJ, Almeida RN 2007. Evaluation of the anticonvulsant activity of alfa-terpineol. Pharm Biol 45: 69-70.

Henry JL, Yashpal K, Pitcher GM, Chabot JG, Coderre TJ 1999. An evidence for tonic activation of NK-1 receptors during the second phase of the formalin test in the rat. $J$ Neurosci 19: 6588-6598.

Holanda-Pinto SA, Pinto LMS, Guedes MA, Cunha GMA, Chaves MH, Santos FA, Rao VS 2008. Antinoceptive effect of triterpenoid $\alpha, \beta$-amyrin in rats on orofacial pain induced by formalin and capsaicin. Phytomedicine 15: 630-634.

Honda K, Kitagawa J, Sessle BJ, Kondo M, Tsuboi Y, Yonehara Y, Iwata K 2008. Mechanisms involved in an increment of multimodal excitability of medullary and upper cervical dorsal horn neurons following cutaneous capsaicin treatment. Mol Pain 19: 4-59.

Hou M, Uddman R, Tajti J, Kanje M, Edvinsson L 2002. Capsaicin receptor immunoreactivity in the human trigeminal ganglion. Neurosci Lett 330: 223-226.

Hu JW, Fiorentino PM, Cairns BE, Sessle BJ 2005. Capsaicininduced inflammation within temporomandibular joint involves VR-1 receptor mechanisms. Oral Biosci Med 4: 241-248.

Ichikawa H, Sugimoto T 2001. VR1-immunoreactive primary sensory neurons in the rat trigeminal ganglion. Brain Res 890: 184-188.

Kamatou GPP, Viljoen AM 2008. Linalool - a review of a biologically active compound of commercial importance. Nat Prod Commun 3: 1183-1192.

Khanna S, Sinclair JG 1992. Responses in the CA1 region of the rat hippocampus to a noxious stimulus. Exp Neurol 117: 28-35.

Khanna S, Zheng F 1999. Morphine reversed formalin-induced CA1 pyramidal cell suppression via an effect on septohippocampal neural processing. Neuroscience 89: 61-71.

Lam DK, Sessle BJ, Hu JW 2009. Glutamate and capsaicin effects on trigeminal nociception II: activation and central sensitization in brainstem neurons with deep craniofacial afferent input. Brain Res 1253: 48-59.

Ling J, Campbell C, Heffernan TM, Greenough CG 2007. Shortterm prospective memory deficits in chronic back pain patients. Psychosom Med 69: 144-148.

Liu M-G, Chen J 2009. Roles of the hippocampal formation in 
pain information processing. Neurosci Bull 25: 237-266.

Lu X, Geng X, Zhang L, Zeng Y, Dong H, Yu H 2009. Substance $\mathrm{P}$ expression in the distal cerebrospinal fluid-contacting neurons and spinal trigeminal nucleus in formalininduced the orofacial inflammatory pain in rats. Brain Res Bull 78: 139-144.

Luccarini P, Childeric A, Gaydier AM, Voisin D, Dallel R 2006. The orofacial formalin test in the mouse: a behavioral model for studying physiology and modulation of trigeminal nociception. Pain 7: 908-914.

Luccarini P, Henry M, Alvarez Gaydier AM, Dallel R 2003. Contribution of neurokinin 1 receptors in the cutaneous orofacial cutaneous pain. Naunyn Schmiedebergs. Arch Pharmacol 368: 320-323.

Mazutti M, Beledelli B, Mossi AJ, Cansian RL, Dariva C, Oliveira JV, Paroul N 2006. Caracterização química de extratos de Ocimum basilicum L. obtidos através de extração com $\mathrm{CO}_{2}$ a altas pressões. Quim Nova 29: 1198-1202.

Melo MS, Sena LCS, Barreto FJN, Bonjardim LR, Almeida JRGS, Lima JT, Quintans-Júnior LJ 2010. Antinociceptive effect of citronellal in mice. Pharm Biol 48: 411-416.

Melzack R 2008. The future of pain. Nat Ver Drug Disov 7: 629.

Miranda HF, Sierralta F, Prieto JC 2009. Synergism between NSAIDs in the orofacial formalin test in mice. Pharmacol Biochem Behav 92: 314-318.

Narita M, Kaneko C, Miyoshi K, Nagumo Y, Kuzumaki N, Nakajima M, Nanjo K, Matsuzawa K, Yamazaki M, Suzuki T 2006. Chronic pain induces anxiety with concomitant changes in opioidergic function in the amygdala. Neuropsychopharmacol 31: 739-750.

Oliveira JS, Porto LA, Estevam CS, Siqueira RS, Alves PB, Niculau ES, Blank AF, Almeida RN, Marchioro M, Quintans-Júnior LJ 2009. Phytochemical screening and anticonvulsant property of Ocimum basilicum leaf essential oil. BLACPMA 8: 195-202.

Onkubo T, Kitamura K 1997. Eugenol activates $\mathrm{Ca}^{+2}$ permeable currents in dorsal root ganglion cells. J Dent Res 76: $1737-1744$

Pace MC, Mazzariello L, Passavanti MB, Sansone P, Barbarisi M, Aurilio C 2006. Neurobiology of pain. J Cell Physiol 209: 8-12.

Peana AT, D'Aquila PS, Chessa ML, Moretti MDL, Serra G, Pippia P 2003. (-)- Linalool produces antinociception in two experimental models of pain. Eur J Pharmacol 460: 37-41.

Peana AT, D'Aquila PS, Panin F, Serra G, Pippia P, Moretti MDL 2002. Anti-inflammatory activity of linalool and linalyl acetate constituents of essential oils. Phytomedicine 9: 721-726.

Peana AT, De Montis MG, Sechi S, Sircana G, D'Aquila PS, Pippia P 2004. Effects of (-)-linalool in the acute hyperalgesia induced by carrageenan, L-glutamate and prostaglandin E2. Eur J Pharmacol 497: 279-284.

Peana AT, Marzocco S, Popolo A, Pinto A 2006. (-)-Linalool inhibits in vitro NO formation: Probable involvement in the antinociceptive activity of this monoterpene compound. Life Sci 78: 719-723.

Pellisier T, Pajot J, Dallel R 2002. The orofacial capsaicin test in rats: effects of different capsaicin concentrations and morphine. Pain 96: 81-87.
Porto LA, Siqueira JS, Seixas LN, Almeida JRGS, QuintansJúnior LJ 2007. Íon channels role in epilepsy and considersof the antiepileptic drugs- a short review. $J$ Epilepsy Clin Neurophysiol 13: 169-175.

Quintans-Júnior LJ, Souza TT, Leite BS, Lessa NMN, Bonjardim LR, Santos MRV, Alves PB, Blank AF, Antoniolli AR 2008a. Phythochemical screening and anticonvulsant activity of Cymbopogon winterianus Jowitt (Poaceae) leaf essential oil in rodents. Phytomedicine 15: 619-624.

Quintans-Júnior LJ, Almeida JRGS, Lima JT, Nunes XP, Siqueira JS, Oliveira LEG, Almeida RN, Athayde-Filho PF, Barbosa-Filho JM 2008b. Plants with anticonvulsant properties - a review. Rev Bras Farmacogn 18: 798-819.

Quintans-Júnior LJ, Melo MS, De Sousa DP, Araújo AAS, Onofre ACS, Gelain DP, Gonçalves JCR, Araújo DAM, Almeida JRGS, Bonjardim LR 2010. Antinociceptive activity of citronellal in formalin-, capsaicin- and glutamateinduced orofacial nociception in rodents and its action on nerve excitability. J Orofac Pain 24: 305-312.

Raboisson P, Dallel R 2004. The orofacial formalin test. Neurosci Biobehav Rev 28: 219-226.

Reanmongkol W, Matsumoto K, Watanabe H, Subhadhirasakul S, Sakai SI 1994. Antinociceptive and antipyretic effects of alkaloids extracted from the stem bark of Hunteria zeylanica. Biol Pharm Bull 17: 134513-134550.

Sanacora G, Zarate CA, Krystal JH, Manji HK 2008. Targeting the glutamatergic system to develop novel, improved therapeutics for mood disorders. Nature Rev 7: 426-437.

Shepherd JD, Huganir RL 2007. The cell biology of synaptic plasticity: AMPA receptor trafficking. Annu Rev Cell Dev Biol 23: 613-643.

Siqueira RS, Bonjardim LR, Araújo AAS, Araújo BES, Melo MGD, Oliveira MGB, Gelain DP, Silva FA, DeSantana JM, Albuquerque-Júnior RLC, Rocha RF, Moreira JCF, Antoniolli AR, Quintans-Júnior LJ 2010. Antinociceptive activity of atranorin in mice orofacial nociception tests. Z Naturforsch C 65: 1-11.

Stoll L, Seguin S, Gentile L 2007. Tricyclic antidepressants, but not the selective serotonin reuptake inhibitor fluoxetine, bind to the S1S2 domain of AMPA receptors. Arch Biochem Biophy 458: 213-219.

Vogt-Eisele AK, Weber K, Sherkheli MA, Panten J, Vielhaber G, Gisselmann G, Hatt H 2007. Monoterpenoid agonists of TRPV3. Br J Pharmacol 151: 530-540.

Waning J, Vriens J, Owsianik G, Stüwe L, Mally S, Fabian A, Frippiat C, Nilius B, Schwab A 2007. A novel function of capsaicin-sensitive TRPV1 channels. Cell Calcium 42: $17-25$.

Zarate CA, Manji HK 2008. The role of AMPA receptor modulation in the treatment of neuropsychiatric diseases. Clin Exp Neuro 211: 7-10.

Zimmermann M 1983. Ethical guidelines for investigations of experimental pain in conscious animals. Pain 16: 109110.

\section{*Correspondence}

Lucindo J. Quintans-Júnior

Departmento de Fisiologia, Universidade Federal de Sergipe

Av. Marechal Rondom, São Cristóvão-SE, Brazil

lucindo@ufs.br; lucindo@pq.cnpq.br

Fax: +55 7932126640 